\title{
Kajian Perkembangan Penggunaan Lahan Permukiman di Koridor Semarang Timur
}

\author{
The Study of the Development of Settlement Land Use in East Semarang Corridor
}

\author{
Iwan Rudiarto ${ }^{1}$ \\ Universitas Diponegoro Semarang, Indonesia \\ Rizqy Ridho Prakasa², Kariza Dewi Wiryanti³, \\ Renni Maharani Putri4, Dinda Kholivia Masykuroh5 \\ Universitas Diponegoro Semarang, Indonesia
}

\begin{abstract}
Abstrak: Pertumbuhan penduduk yang tinggi menuntut pemerintah untuk menyediakan kebutuhan akan rumah yang layak huni dan terjangkau bagi seluruh lapisan masyarakat serta dilengkapi fasilitas pelayanan umum. Lokasi merupakan salah satu faktor penting dalam pemilihan rumah. Rumah yang berada di pusat kota memudahkan bagi penghuni untuk melakukan aktiftas sehari-hari dengan meminimalisir biaya transportasi. Saat ini ketersediaan lahan di pusat kota tidak mampu memenuhi perkembangan perumahan. Fenomena ini membuat perkembangan perumahan bergeser ke daerah pinggiran. Tujuan dari penelitian ini ialah mengkaji perkembangan penggunaan lahan permukiman di daerah pinggiran koridor Semarang Timur. Penelitian ini menggunakan metode pendekatan pemodelan spasial yang menggambarkan kondisi nyata di lapangan. Perkembangan Penggunaan Lahan Permukiman pada tahun 2002, 2006 dan 2011 menunjukkan bahwa lahan permukiman semakin berkembang. Jika dilihat pada arah perkembangan yang terjadi, pemusatan permukiman cenderung semakin padat kearah perbatasan Kota Semarang dengan Kabupaten Demak. Begitu juga dengan arah kepadatan penduduk yang cenderung berkembang kearah pinggiran tersebut.
\end{abstract}

Kata kunci: penggunaan lahan; permukiman; daerah pinggiran

\begin{abstract}
The increasing number of population requires the government to supply adequate and affordable housing for all level of societies with the amenities. Location is the important thing in determining a house to settle. Housing in the central of the city facilitates the tenant to do daily activities by minimizing the cost of transportation. Nowadays, the availability of land in the city centre can not be able to fulfill the housing demand. This phenomenon makes the housing development move toward the suburb. The purpose of this research is to assess the development of land settlement in the Eastern Semarang Suburb. This research method using spatial modeling approach that describes the real conditions in the area research. The development of land use Settlement in 2002, 2006 and 2011 showed thatincreasing settlement land. If the views on the direction of development going on, the concentration of settlements tend to be increasingly dense towards the border town of Demak Regency Semarang. So does the direction of population density that tends to develop towards the suburbs.
\end{abstract}

Keywords: land use; settlement; suburb

\footnotetext{
Korespondensi Penulis: Universitas Diponegoro, Semarang, Indonesia Email: iwan.rudiarto@undip.ac.id

2 Korespondensi Penulis: Universitas Diponegoro, Semarang, Indonesia Email: rizqy.ridho15@pwk.undip.ac.id

3 Korespondensi Penulis: Universitas Diponegoro, Semarang, Indonesia Email: kariza.dewi15@pwk.undip.ac.id

${ }^{4}$ Korespondensi Penulis: Universitas Diponegoro, Semarang, Indonesia Email: rennimaharani@gmail.com

5 Korespondensi Penulis: Universitas Diponegoro, Semarang, Indonesia Email: dinda.kholivia15@pwk.undip.ac.id
} 
Pendahuluan

\section{Perkembangan \\ Penggunaan Lahan Permukiman di Koridor Semarang Timur}

Pertambahan penduduk setiap tahun terjadi di kota-kota besar di Indonesia, salah satunya Kota Semarang. Kota Semarang mengalami laju pertumbuhan yang meningkat dari tahun ke tahunnya. Pada tahun 2012 jumlah penduduk Kota Semarang 1.559.168 jiwa, dimana jumlah penduduk di pusat kota yang berada di Kecamatan Semarang Tengah dan Semarang Selatan yakni 154.605 jiwa (RKPD Kota Semarang, 2014). Apabila diasumsikan satu keluarga terdiri dari 5 orang yaitu ayah, ibu, dan anak menghuni dalam satu unit rumah (Soetalaksana, 2000; 8), maka pada tahun 2012 kebutuhan akan rumah di pusat kota sebesar 30.921 unit rumah. Pada kenyataannya rumah di pusat kota yang tersedia dan tergolong gedung permanen berjumlah 23.648 unit rumah, maka penyediaan rumah di pusat kota masih kurang 7.273 unit rumah untuk mengatasi laju pertumbuhan penduduk di Kota Semarang.

Pergeseran perkembangan permukiman terjadi di koridor Semarang Timur, dimana koridor ini dijadikan sebagai penampung perkembangan penduduk dari pusat kota. Koridor Semarang Timur yang dulunya didominasi oleh pertanian dan perkebunan, saat ini terjadi alih fungsi lahan menjadi kantong-kantong permukiman yang berkembang tiap tahunnya. Perkembangan permukiman ini ada yang tidak direncanakan dan ada yang direncanakan. Kantong-kantong permukiman yang tidak terencana tumbuh dan berkembang dengan sendirinya oleh masyarakat desa, sehingga menimbulkan pola-pola yang tidak teratur dan menyebabkan permasalahan urban sprawl di daerah pinggiran.

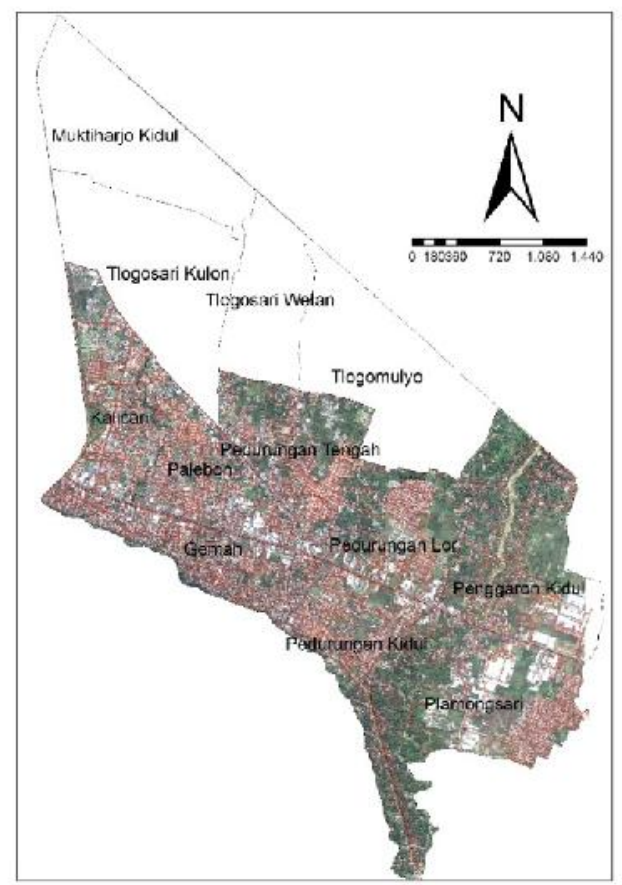

\section{Gambar 1. Peta Wilayah Studi Koridor Semarang Timur}

Pengertian perkembangan kota itu sendiri menurut Kurniawati (2007) adalah suatu proses perubahan keadaan-kekeadaan yang lain dalam waktu yang berbeda. Menurut Branch (1995) dalam Kurniawati (2007) proses perubahan yang terjadi, sangat dipengaruhi oleh situasi dan kondisi internal yang menjadi unsure terpenting dalam perencanaan kota secara komperhensif. Perkembangan kota menurut Yunus (2000) terjadi dalam tiga proses, yaitu: perembetan meloncat, memanjang, dan kosentris. Berbeda dengan Yunus, menurut Zahnd (2006) proses perkembangan di dalam kota dibagi menjadi tiga, yaitu: perkembangan horizontal, perkembangan vertikal, dan perkembangan interstisial.

Terdapat dua pendapat mengenai lahan menurut Roberts (1992) dalam Catanese \& Synder (1992), pendapat pertama mengatakan lahan merupakan harta kekayaan, yaitu komoditas untuk dimiliki, dimanfaatkan, diperjual-belikan demi kesenangan atau keuntungan pribadi. Pendapat yang lainnya mengatakan bahwa lahan adalah sumber daya milik bersama, sama seperti udara dan air, yang harus dilestarikan dan dipelihara dengan mempertimbangkan secara tepat dampaknya 


\section{Metodelogi Penelitian}

\section{Karakteristik Masyarakat Koridor Semarang Timur}

terhadap masyarakat sebagai keseluruhan dan pada kondisi ketika sumber daya alam milik bersama itu kelak diwariskan pada generasi yang akan datang. Penggunaan lahan menurut Arsyad (1989) dalam As-syakur (2011) ialah merupakan hasil akhir dari setiap bentuk campur tangan kegiatan (intervensi) manusia terhadap lahan di permukaan bumi yang bersifat dinamis dan berfungsi untuk memenuhi kebutuhan hidup baik material maupun spiritual. Utoyo (2012) menjelaskan bahwa faktor-faktor yang diduga berpengaruh terhadap penggunaan lahan ialah jenis bahan induk yang menentukan tingkat kesuburan lahan, setelah itu juga menentukan pola penggunaan lahan dan konsentrasi penduduk.

Penelitian ini menggunakan pendekatan pemodelan spasial yang menggambarkan kondisi nyata di lapangan. Pendekatan penelitian yang digunakan dalam penelitian ini yaitu jenis pendekatan kuantitatif. Metode kuantitatif merupakan metode yang digunakan untuk menganalisis data-data tersaji dalam bentuk angka dan terukur. Tahap awal yang dilakukan untuk mencapai tujuan dalam penelitian ini adalah menelaah teori-teori meupun konsep melalui beberapa literatur dan jurnal yang relevan. Kemudian dilanjutkan dengan survei lapangan untuk mengkaji fenomena dilapangan. Hasil survei tersebut kemudian dianalisis agar dapat menghasilkan temuan studi yang sesuai dengan tujuan penelitian.

Objek penelitian merupakan objek yang akan digunakan dalam penelitian. Sedangkan subjek penelitian merupakan subjek yang akan digunakan dalam penelitian. Objek dalam penelitian ini adalah perkembangan penggunaan lahan permukiman. Sedangkan subjek penelitian adalah koridor Semarang Timur. Informan merupakan sumber data yang akan digunakan pada penelitian ini. Informan harus memahami secara mendalam mengenai kondisi terkait objek penelitian, yaitu perkembangan penggunaan lahan permukiman di daerah pinggiran. Informan pada penelitian ini adalah masyarakat yang bertempat tinggal di daerah pinggiran koridor Semarang Timur sehingga mengetahui perkembangan dari kondisi yang terjadi lapangan.

Mata pencaharian merupakan komponen pokok dalam kehidupan. Mempunyai mata pencaharian dapat diartikan mempunyai penyambung hidup karena dari hasil bekerja mendapatkan penghasilan untuk memenuhi kebutuhan sehari-hari. Begitu juga yang dilakukan oleh masyarakat Koridor Semarang Timur yang mempunyai mata pencaharian sesuai dengan keahliannya.

Penduduk Koridor Semarang Timur memiliki laju pertumbuhan penduduk yang terus meningkat. Hal ini dapat dilihat pada gambar 1 pada tahun 2002 jumlah total penduduk di koridor ini adalah 129.923 jiwa. Angka ini terus meningkat dibuktikan pada tahun 2006 jumlah total penduduk mencapai angka 157.124 jiwa. Selanjutnya pada tahun 2011 jumlah penduduk Koridor Semarang Timur 174.133 jiwa. Sama halnya dengan pertumbuhan penduduk, luas lahan permukiman di Koridor Semarang Timur juga mengalami peningkatan. Pada tahun 2002 luas lahan permukiman yaitu $5.381 \mathrm{~km}^{2}$. Sedangkan pada tahun 2006 luas lahan permukiman yaitu $5.637 \mathrm{~km}^{2}$ dan luas lahan permukiman pada tahun 2011 adalah $7.347 \mathrm{~km}^{2}$.

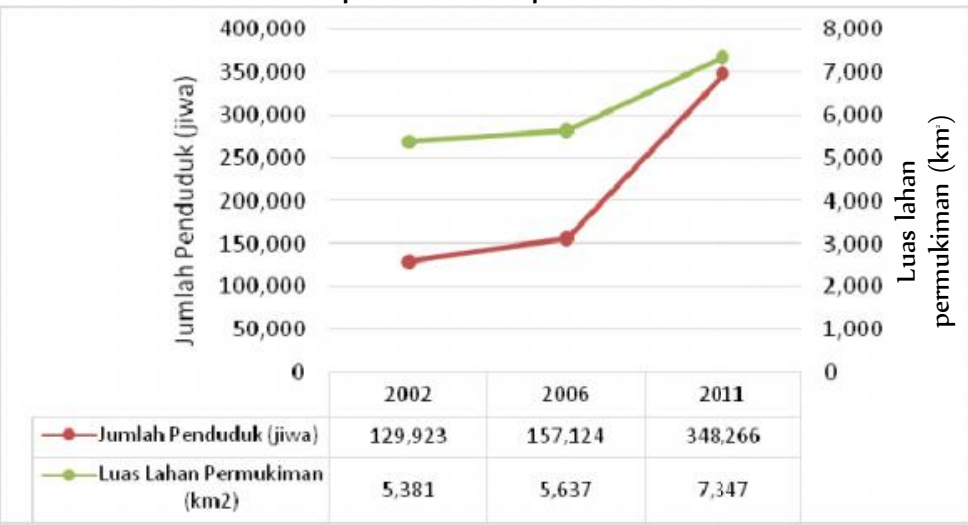

Gambar 1. Grafik Laju Pertumbuhan Penduduk dan Luas Permukiman Koridor Semarang Timur Tahun 2002, 2006 dan 2011 
Dilihat dari komposisi penduduk berdasarkan usia, Kecamatan ini didominasi oleh usia produktif yaitu pada usia 10 - 54 tahun. Sedangkan untuk usia lanjut angka ini semakin menurun. Berikut merupakan piramida penduduk Koridor Semarang Timur.

Penduduk Koridor Semarang Timur didominasi oleh penduduk perempuan dengan angka penduduk perempuan 71.432, 78.964, 88.033 jiwa pada tahun 2002, 2006 dan 2011. Sedangkan jumlah penduduk laki-laki pada tahun 2002, 2006, dan 2011 adalah 70.205, 78.187, dan 86.100 jiwa.
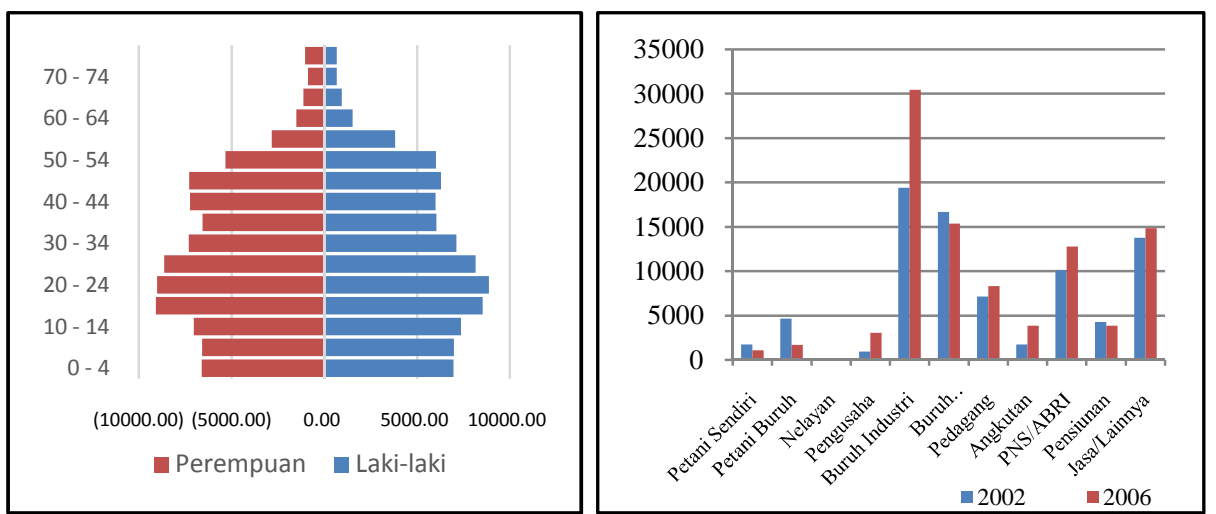

Gambar 2. a) Piramida Penduduk Koridor Semarang Timur; b) Jumlah Penduduk menurut mata pencaharian Koridor Semarang Timur

Mata pencaharian merupakan komponen pokok dalam kehidupan. Mempunyai mata pencaharian dapat diartikan mempunyai penyambung hidup karena dari hasil bekerja mendapatkan penghasilan untuk memenuhi kebutuhan sehari-hari. Begitu juga yang dilakukan oleh masyarakat Koridor Semarang Timur yang mempunyai mata pencaharian sesuai dengan keahliannya.

Mata pencaharian penduduk Koridor Semarang Timur didominasi oleh mata pencaharian sebagai buruh industri. Hal tersebut dapat terlihat pada grafik diatas bahwa buruh industri jumlahnya paling banyak diantara mata pencaharian lainnya. Sedangkan mata pencaharian yang paling sedikit adalah sebagai nelayan. Jika dibandingkan jumlah penduduk berdasarkan mata pencarian antara tahun 2002 dengan 2006 terlihat bahwa kenaikan yang cukup mencolok terjadi pada mata pencaharian buruh industri. Pada tahun 2002 jumlahnya hanya 19.395 orang sedangkan pada tahun 2006 menjadi 30.459 orang. Sedangkan mata pencaharian lainnya ada yang mengalami kenaikan dan penurunan namun tidak begitu signifikan.

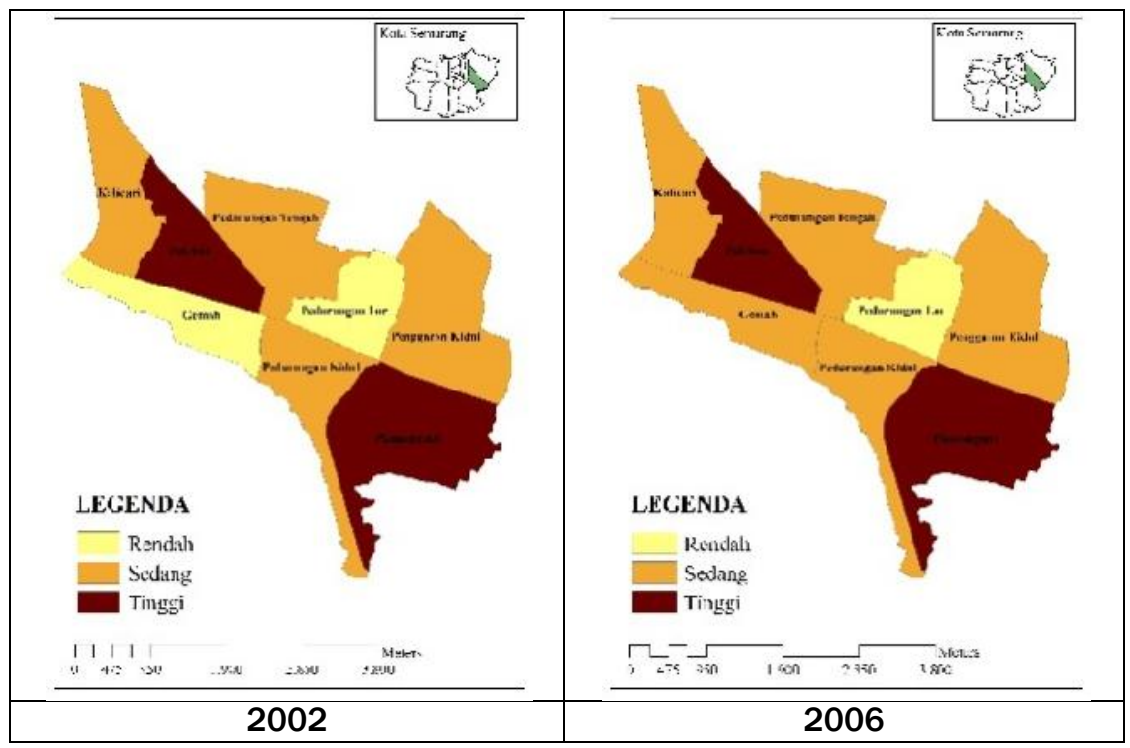


Penggunaan Lahan Pemukiman Koridor Semarang Timur

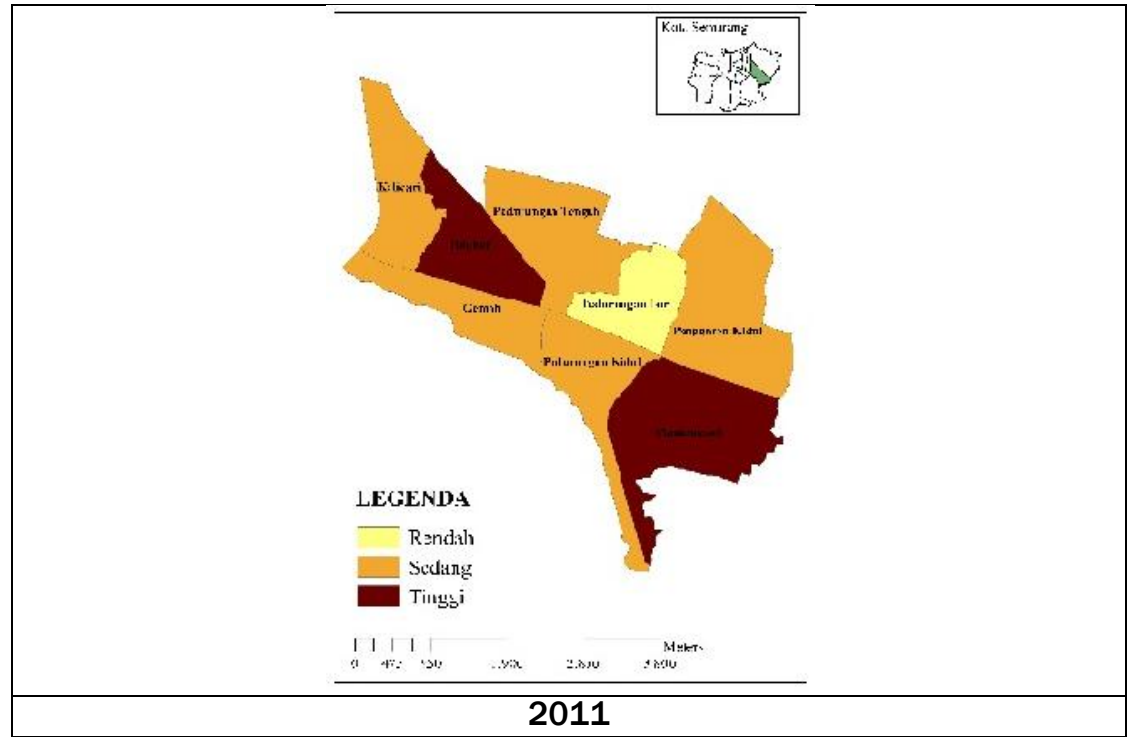

\section{Gambar 3. Peta Kepadatan Penduduk Koridor Semarang Timur Tahun 2002, 2006, dan 2011}

Koridor Semarang Timur tidak terlepas dari fenomena perkembangan Kota Semarang ke arah pinggiran. Peningkatan lahan permukiman dapat dilihat di sepanjang jalan arteri Semarang-Purwodadi yang melintasi 8 (delapan) kelurahan di Koridor Semarang Timur.

Tabel 1. Intensitas Interaksi Sosial yang Berlangsung

\begin{tabular}{|c|c|c|c|c|c|c|c|}
\hline \multirow[b]{2}{*}{ No } & \multirow[b]{2}{*}{ Kelurahan } & \multicolumn{3}{|c|}{ Luas Lahan Permukiman (Ha) } & \multicolumn{3}{|c|}{ Perubahan } \\
\hline & & 2002 & 2006 & 2011 & $\begin{array}{l}2002- \\
2006\end{array}$ & 2006-2011 & $2002-2011$ \\
\hline 1 & Gemah & 78.73 & 78.73 & 115.60 & $0 \%$ & $47 \%$ & $\begin{array}{r}36.87 \mathrm{Ha} \\
(47 \%)\end{array}$ \\
\hline 2 & Kalicari & 47.06 & 47.06 & 73.36 & $0 \%$ & $56 \%$ & $\begin{array}{r}26.3 \mathrm{Ha} \\
(56 \%)\end{array}$ \\
\hline 3 & Palebon & 88.24 & 88.24 & 97.29 & $0 \%$ & $10 \%$ & $\begin{array}{r}9.05 \mathrm{Ha} \\
(10 \%)\end{array}$ \\
\hline 4 & PedurunganKidul & 90.11 & 91.21 & 102.70 & $1 \%$ & $13 \%$ & $\begin{array}{r}12.59 \mathrm{Ha} \\
(14 \%)\end{array}$ \\
\hline 5 & PedurunganLor & 49.53 & 49.53 & 65.94 & $0 \%$ & $33 \%$ & $\begin{array}{r}16.41 \mathrm{Ha} \\
(33 \%)\end{array}$ \\
\hline 6 & Pedurungan Tengah & 80.75 & 82.27 & 105.74 & $2 \%$ & $29 \%$ & $\begin{array}{r}24.99 \mathrm{Ha} \\
(31 \%)\end{array}$ \\
\hline 7 & PenggaronKidul & 34.25 & 43.03 & 67.96 & $26 \%$ & $58 \%$ & $\begin{array}{r}33.71 \mathrm{Ha} \\
(84 \%)\end{array}$ \\
\hline 8 & Plamongsari & 69.42 & 83.66 & 106.08 & $21 \%$ & $27 \%$ & $\begin{array}{r}36.66 \mathrm{Ha} \\
(48 \%)\end{array}$ \\
\hline
\end{tabular}

Berdasarkan tabel 1, ada 4 kelurahan yang tidak mengalami pertumbuhan luas permukiman dari tahun 2002 hingga 2006 yaitu Kelurahan Gemah, Kalicari, Palebon, dan Pedurungan Lor. Sementara pada tahun 2011, luas lahan permukiman mulai meningkat di semua kelurahan. Peningkatan tertinggi terjadi di Kelurahan Penggaron Kidul mencapai 58\% sedangkan perningkatan terendah pada tahun 2014 terjadi di Kelurahan Palebon hanya sebesar 10\%. 


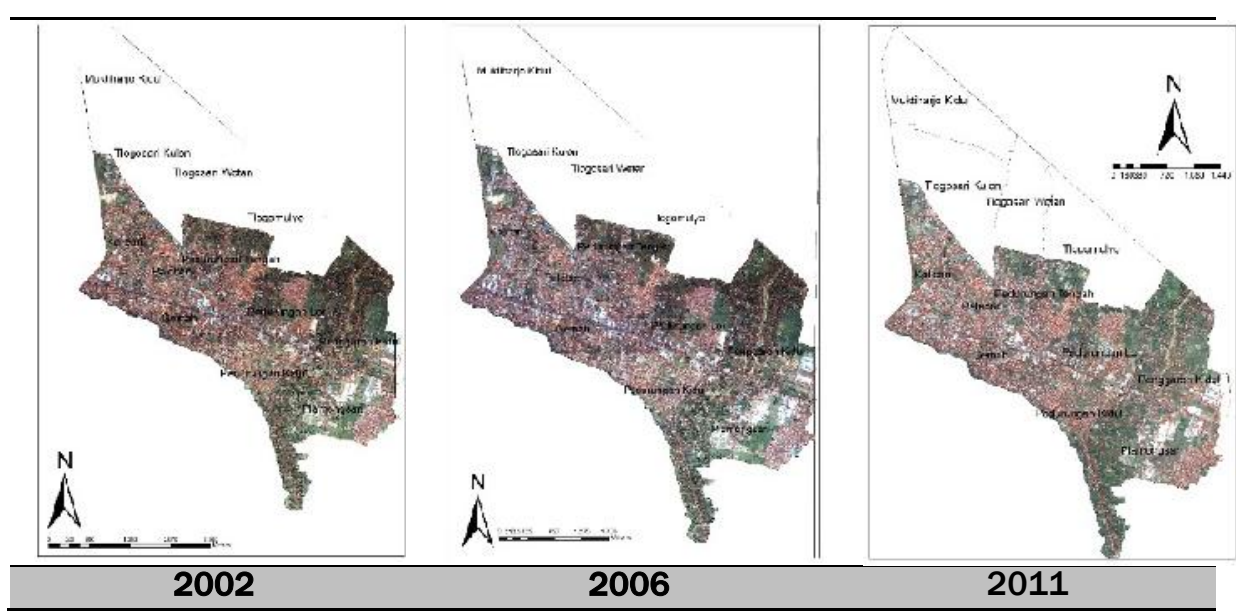

Gambar 4. Peta Citra Ikonos Koridor Semarang Timur Tahun 2002, 2006, dan 2011

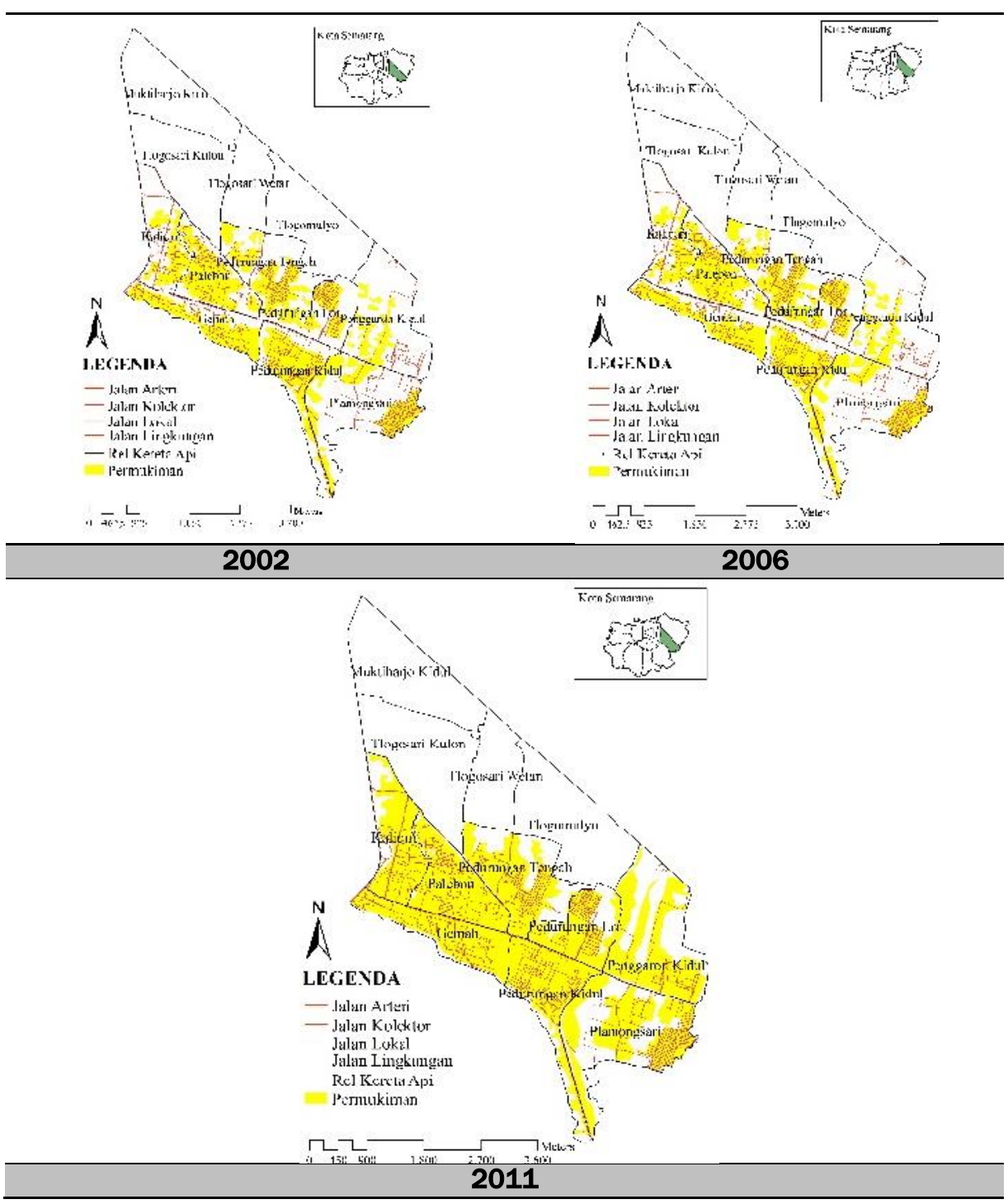

Gambar 5. Peta Penggunaan Lahan Permukiman Koridor Semarang Timur Tahun 2002, 2006, dan 2011 
Pola dan Struktur Ruang Koridor Semarang Timur

Perkembangan penggunaan lahan permukiman yang terjadi di Koridor Semarang Timur berdampak pada pola dan struktur ruang. Pada analisis ini akan melihat perkembangan pola dan struktur yang terjadi pada tahun 2002, 2006, dan tahun 2011. Pada Gambar 6. Pola perkembangan yang terjadi pada tahun 2002, 2006 hingga 2011 tidak berubah yakni pola perkembangan secara linier. Dimana perkembangan yang terjadi mengikuti oleh perkembangan aksesbilitas atau jalan, berupa jalan arteri, jalan kolektor, dan jalan lingkungan. Pola perkembangan yang terjadi juga bersifat radial, dimana sifat ini tidak terus menerus sama dengan awal perkembangannya memusat dalam satu wilayah, melainkan ditahun selanjutnya perkembangannya bersifat tidak merata. Selain itu struktur ruang yang terbentuk, menunjukkan model struktur ruang banyak pusat. Dimana pada wilayah koridor Semarang Timur ini memiliki wilayah sebagai pusat kegiatan dan wilayah sebagai sub pusat kegiatan.
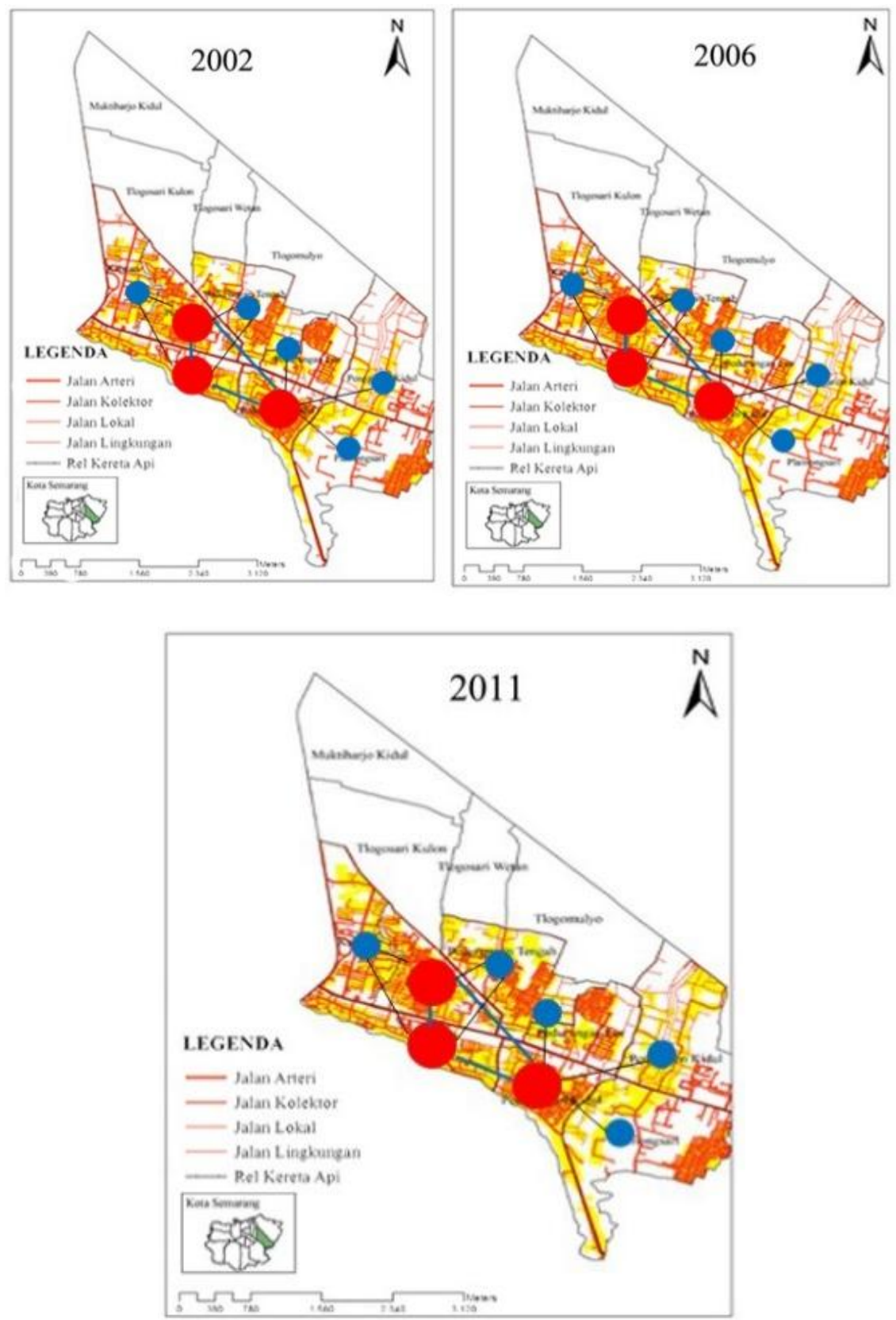

Gambar 6. Pola Ruang Koridor Semarang Timur Tahun 2002, 2006, dan 2011 
Struktur Kota di koridor Semarang Timur dengan penggunaan lahan permukiman yang lebih memfokuskan pada pusat kota dan sepanjang jalan transportasi mengindikasikan strutur ruang sesuai dengan teori sektor. Dimana Koridor Semarang Timur memiliki beberapa kawasan, meliputi: kawasan permukiman, kawasan perdagangan dan jasa, kawasan pendidikan, kawasan pemerintahan, serta kawasan permukiman. Kawasan perdagangan dan jasa terletak di pinggir-pinggir jalan besar, seperti jalan arteri dan jalan kolektor. Kawasan permukiman letaknya di belakang kawasan perdagangan dan jasa. Dimana dalam kawasan permukiman terdapat fasilitas-fasilitas pendukung seperti pendidikan dan kesehatan. Struktur kota koridor Semarang Timur menunjukkan bahwa teradapat 3 kawasan yang ada di koridor Semarang Timur yakni: Kawasan CBD, low-class residence, dan high-class residence. Dimana kawasan CBD ini merupakan kawasan perdagangan dan jasa. Sedangkan low-class residence merupakan perkampungan yang ada di koridor Semarang Timur dan high-class residence berupa perumahan yang berdiri di koridor Semarang Timur.

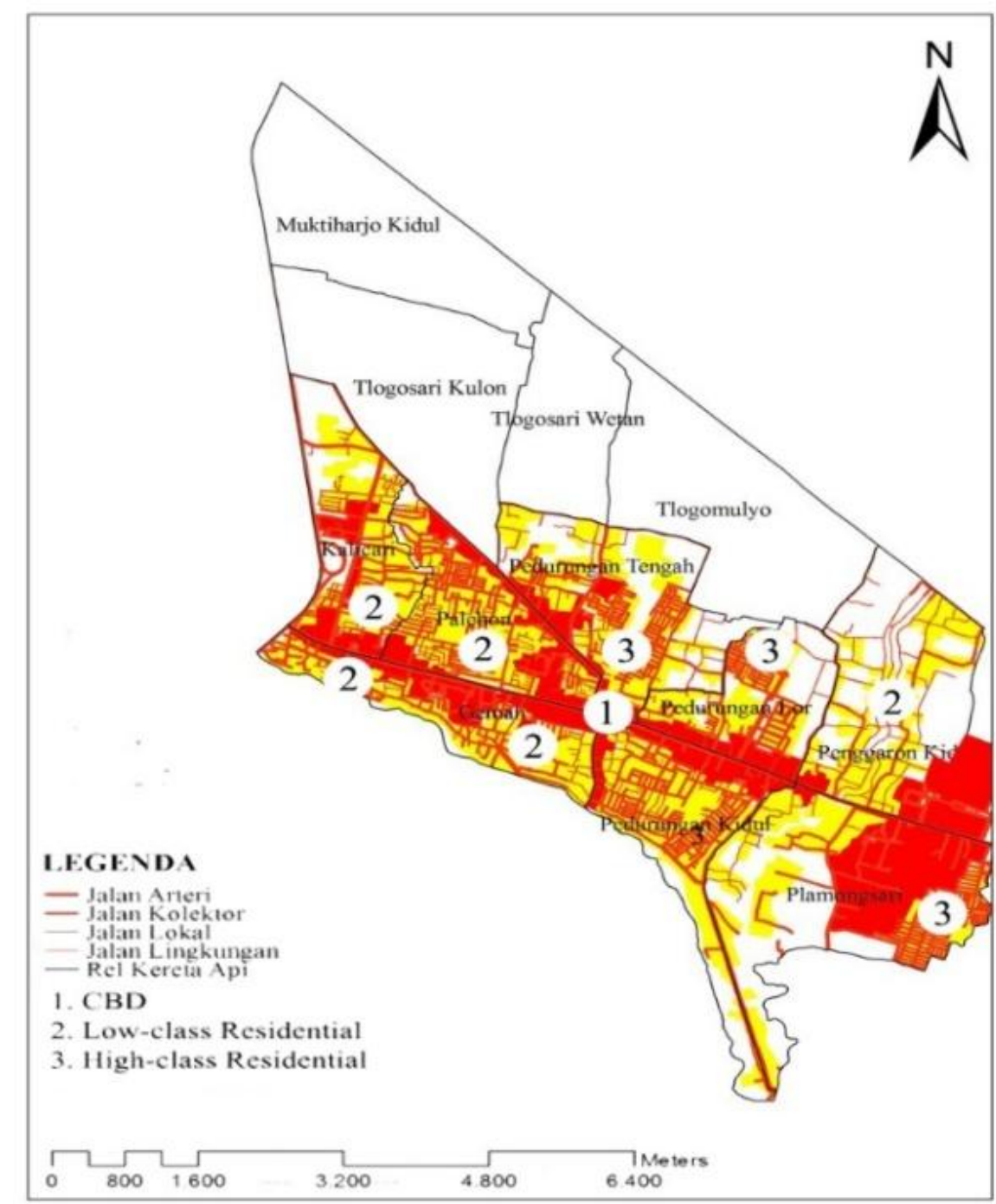

\section{Gambar 7. Struktur Ruang Koridor Semarang Timur}

Pada tahun 2002 jumlahnya hanya 19.395 orang sedangkan pada tahun 2006 menjadi 30.459 orang. Sedangkan mata pencaharian lainnya ada yang mengalami kenaikan dan penurunan namun tidak begitu signifikan. 


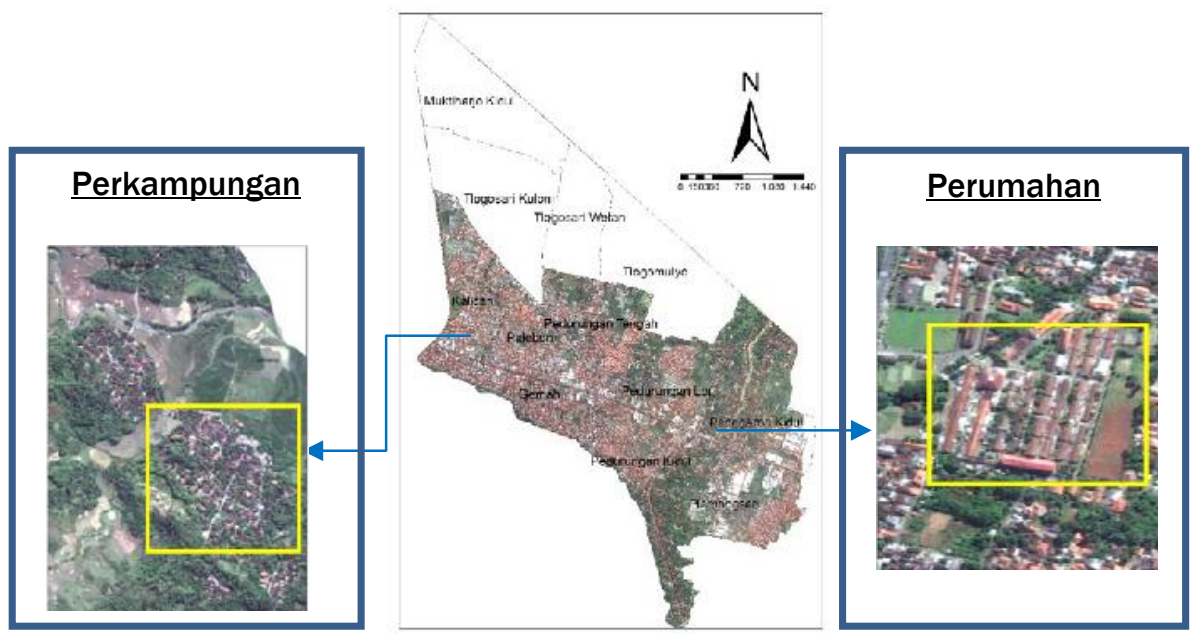

Gambar 9. Pola Ruang Perumahan dan Perkampungan Koridor Semarang Timur

Perumahan yang ada di koridor Semarang Timur memanfaatkan jalan utama pada Koridor Semarang Timur sebagai penghubung menuju ke perumahan tersebut. Orientasi bangunannya menghadap ke muka jalan. Pola bangunannya tersusun rapi dengan bentuk pola jaringan jalan grid. Pola jalan seperti ini memiliki keuntungan dengan keamanannya, tetapi terdapat kelemahan yakni pengguna jalan terasa bosan.

Pola perkembangan perkampungan di Koridor Semarang Timur tata letak bangunannya di rapi dan tidak terencana dengan baik. Kondisi jalan di koridor ini belum semua berjenis aspal. Selain itu masih terdapat jalanan yang berlubang. Kondisi rumah perkampungan ini juga masih ada yang semipermanen. Sebagian besar masyarakat yang bertempat tinggal disini merupakan warga asli, yang sudah menetap lebih dari 10 tahun. Dari hasil temuan di lapangan, masyarakat menyatakan pembangunan rumah sebagian dilakukan dengan swadaya. Hal ini menandakan masih terdapat karakteristik masyarakat daerah pinggiran yakni memiliki rasa gotong royong yang tinggi. Masyarakat yang bertempat tinggal di perkampungan mengaku bahwa, perkembangan yang terjadi di daerah pinggirian khususnya Koridor Semarang Timur cukup cepat dan berkembang luas. Dimana dulunya masih banyak lahan untuk persawahan dan sepi akan bangunan, saat ini penuh dengan lahan yang terbangun. Selain itu, sebagian besar masyarakat pendatang yang bertempat tinggal di kawasan Koridor Semarang Timur.

Kesimpulan

Perkembangan Kota Semarang saat ini bergeser ke daerah pinggiran. Hal ini terlihat di Koridor Semarang Timur yang merupakan salah satu daerah pinggiran di Kota Semarang. Hasil penelitian ini menunjukkan bahwa Koridor Semarang Timur berkembang semakin pesat setiap tahunnya. Peta perkembangan penggunaan lahan permukiman pada tahun 2002, 2006 dan 2011 menunjukkan bahwa lahan permukiman semakin berkembang.

Analisis tersebut menunjukkan bahwa koridor ini memiliki pola ruang yang berjenis banyak pusat. Pusat-pusat tersebut berjumlah 3 pusat diantaranya adalah Kelurahan Palebon, Gemah, dan Pedurungan Kidul.

Perkembangan koridor ini juga terlihat pada analisis struktur ruang yang menunjukkan banyaknya aktivitas baru yang muncul di koridor ini seperti CBD, low, medium dan high residential. jika dilihat pada arah perkembangan yang terjadi, pemusatan permukiman cenderung semakin padat kearah perbatasan Kota Semarang dengan Kabupaten Demak. Begitu juga dengan arah kepadatan penduduk yang cenderung berkembang kearah pinggiran tersebut. Pesatnya perkembangan ini selayaknya menjadi perhatian yang lebih bagi Pemerintah Kota Semarang untuk melakukan persebaran dan pemerataan penduduk sehingga pemusatan dan disparitas ruang tidak terjadi. 
Daftar Pustaka
As-syakur, Abd. Rahman. 2011. "Perubahan Penggunaan Lahan di Provinsi Bali", dalam jurnal EcotrophicVol. 6/ No. 1. Bali. PusatPenelitian Lingkungan Hidup (PPLH) Universitas Udayana.

BAPPEDA Kota Semarang. Rencana Kerja Pemerintah Daerah Kota Semarang tahun 2014

Catanese, Anthony J dan James C. Synder. 1992. Urban Planning, Second Edition.

Kurniawati, Feri Ema. 2010. “Perkembangan Struktur Ruang Kota Semarang Periode 1960-2007 (Studi Pengembangan Struktur Ruang dari Masa Pasca Kolonial Sampai 2007)", Skripsi S-1 Fakultas Geografi Universitas Muhammadiyah Surakarta.

Soetalaksana, Tito. 2000. "Aspek PembiayaanPerumahan, Khususnya RS/ RSS", dalam majalah usahawan. No 03 Tahun XXIX. Maret. Hal. 8. Jakarta: Erlangga.

Yunus, Hadi Sabari. 2000. Struktur Tata Ruang Kota. Yogyakarta: PustakaPelajar.

Zahnd, Markus. 2006. Perancangan Kota Secara Terpadu: Teori Perancangan Kota Dan Penerapannya. Yogyakarta: Kanisius. 